\title{
Effects of the Insulin-like Growth Factor Pathway on the Regulation of Mammary Gland Development
}

\author{
Woo Tae Ha ${ }^{1}$, Ha Yeon Jeong ${ }^{2}$, Seung Yoon Lee ${ }^{3}$ and ${ }^{\dagger}$ Hyuk Song ${ }^{1}$ \\ ${ }^{1}$ Dept. of Stem Cell and Regenerative Biology, College of Animal Bioscience and Technology, \\ Konkuk University, Seoul 143-701, Korea \\ ${ }^{2}$ Dept. of Animal Resources Development Dairy Science Division, RDA, Cheonan 331-801, Korea \\ ${ }^{3}$ Swine Consulting Group, HanByol Farm Tech, Gyeonggi 463-785, Korea
}

\begin{abstract}
The insulin-like growth factor (IGF) pathway is a key signal transduction pathway involved in cell proliferation, migration, and apoptosis. In dairy cows, IGF family proteins and binding receptors, including their intracellular binding partners, regulate mammary gland development. IGFs and IGF receptor interactions in mammary glands influence the early stages of mammogenesis, i.e., mammary ductal genesis until puberty. The IGF pathway includes three major components, IGFs (such as IGF-I, IGF-II, and insulin), their specific receptors, and their high-affinity binding partners (IGF binding proteins [IGFBPs]; i.e., IGFBP1-6), including specific proteases for each IGFBP. Additionally, IGFs and IGFBP interactions are critical for the bioactivities of various intracellular mechanisms, including cell proliferation, migration, and apoptosis. Notably, the interactions between IGFs and IGFBPs in the IGF pathway have been difficult to characterize during specific stages of bovine mammary gland development. In this review, we aim to describe the role of the interaction between IGFs and IGFBPs in overall mammary gland development in dairy cows.
\end{abstract}

Key words : Mammogenesis, IGF pathway, IGFBPs, Dairy cow, Mammary gland

\section{INTRODUCTION}

Mammary glands are anatomical structures that distinguish mammals from all other animals and secrete milk for offspring. These organs are considered composite secretory organs and are made up of various types of cells, including epithelial cells, adipocytes, fibroblasts, and vascular endothelial cells (Macias \& Hinck, 2012). There are three major stages of mammary gland development: embryonic, pubertal, and reproductive stages. In embryonic mammary gland develop- ment, the epithelial and surrounding stromal compartments derived from embryonic ectoderm and mesoderm are formed. The epithelial placodes of ectoderm formation during early embryo development give rise to the mammary gland structures during morphogenesis (Pispa \& Thesleff, 2003). The placodes fundamentally regulate epithelial-mesenchymal interactions and generate the rudimentary ductal structure of the gland present at birth. The puberty and reproductive stages of mammary gland development occur continuously through hormonal regulation associated with pubertal growth, pre-

\footnotetext{
Manuscript received June 29, 2016, Received in revised form July 19, 2016, Accepted August 30, 2016

${ }^{\dagger}$ Corresponding Author : Hyuk Song, Dept. of Stem Cell and Regenerative Biology, College of Animal Bioscience and Technology, Konkuk University, Seoul 143-701, Korea. Tel. : +82-2-2450-0562, E-mail : songh@konkuk.ac.kr

This is an Open Access article distributed under the terms of the Creative Commons Attribution Non-Commercial License (http:// creativecommons.org/licenses/by-nc/3.0) which permits unrestricted non-commercial use, distribution, and reproduction in any medium, provided the original work is properly cited.
} 
gnancy, lactation, and involution. At birth, the mammary gland is a rudimentary structure consisting of only a few small ducts. These small ducts can grow allometrically following the growth phase and undergo expansion, called ductal morphogenesis, until puberty. Puberty in mammals initiates morphogenesis of branched structures in the mammary gland; this process is mutually regulated by growth hormone $(\mathrm{GH})$, estrogen, and insulin-like growth factor (IGF)1 to generate a ductal tree (Howlin et al., 2006). During pregnancy, alveoli of the mammary glands, which secrete milk, are generated through combined action of progesterone and prolactin (PRL). In the mature structure, short branched ducts are controlled by progesterone; however, alveologenesis occurs only during pregnancy through induction by PRL and progesterone. PRL continually stimulates this process until the lactogenesis stage. When the levels of progesterone and PRL increase in the serum, branched alveoli are developed, and adipose tissue and blood flow are increased. After achieving milk production, PRL is decreased, and involution, defined as remodeling back to the original adult state, occurs. In bovines, colostrum is secreted during late gestation and for the first few days after calving. In this review, we will focus on the IGF pathway and its role in developmental processes and involute interactions in bovine mammary glands components.

\section{The IGF Pathway in Bovine Mammary Glands}

The IGF pathway consists of three ligands (IGF-I, IGFII, and insulin), their receptors (IGF-IR, IGF-IIR, and insulin receptor), high-affinity binding proteins (IGF binding protein [IGFBP] 1-6), and their specific proteases (Le Roith, 2003); the complex interactions among these components maintain cellular mechanisms. As shown in Fig. 1, these IGF ligands play various roles in mammalian growth, development, and metabolism and act as endocrine factors that prevent apoptotic signaling. Mammary epithelial cells are influenced by many components of the IGF system, particularly IGFBPs.

The interactions between IGFs and IGFBPs have been shown to inhibit IGF-I or IGF-II binding with IGF-IR and IGF-IIR through competitive mechanisms (Kelley et al., 1996). Bovine mammary epithelial cells have been reported to express all three IGF receptors (Hadsell et al., 1990), to synthesize IGFBPs (Gibson et al., 1999), and to produced IGF-II (Baumrucker et al., 1993). IGF-1 mRNA is expressed in mammary glands of pregnant and lactating cows (Glimm et al., 1992; Sharma et al., 1994), whereas cultured primary mammary gland cells do not exhibit $I G F-1$ expression. Recent studies have suggested that IGF-I plays a critical role in growth hormone $(\mathrm{GH})$-induced mammary ductal growth

The IGF and GH interaction is important for regulation of mammalian epithelial cell proliferation and differentiation. IGF-I is circulated through its interaction with GH, which is the major inducer of alveolar growth (Kleinberg, 1997). There are correlations between IGF-I and GH expression, and these correlations may directly mediate mammary growth (Ruan et al., 1992). Additionally, GH has been shown to induce IGF-I expression in mammary tissue (Ruan et al., 1995). Furthermore, IGF-I can promote ductal development in implanted mammary glands and synergizes with estrogen to support the generation of terminal end buds (TEBs) and ductal elongation in ovariectomized mice (Ruan et al., 1995; Kleinberg, 1997). IGFs are potential mediator involved in the regulation of cell proliferation and apoptosis.

Several studies have reported that IGF-I and IGFR interactions are associated with cell proliferation and apoptosis through inhibition of Wnt signaling (Richard-Parpaillon et al., 2002; Rota \& Wood, 2015). IGF may specifically influence IGF-1R owing to its greater binding affinity than IGF-II or insulin (Jones \& Clemmons, 1995). Moreover, IGF-IIR binds more specifically to IGF-II than IGF-I and does not bind with insulin (Massague et al., 1982; Rechler \& Nissley, 1985). In general, mammary gland development is characterized by 


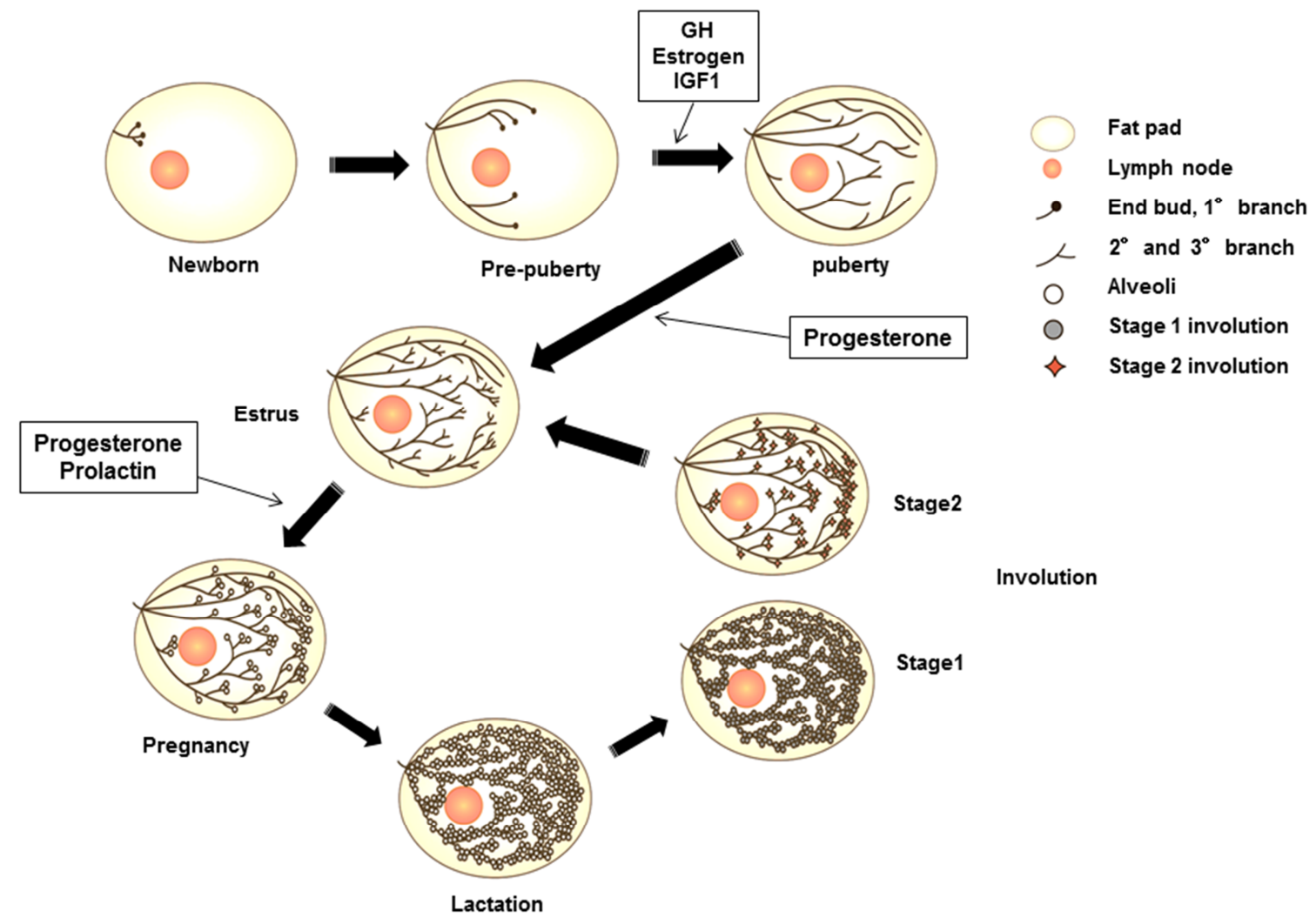

Fig. 1. Illustration depicting the stages of postnatal mammary gland development.

ductal growth in nonpregnant heifers. While IGF-I is highly expressed during the early stages of mammogenesis when compared with that during lactation, this protein exhibits potential proliferative functions throughout the entire process of bovine mammary gland development. Additionally, $I G F-1 R$ and $\mathrm{GH}$ receptor mRNA expression levels are decreased during the lactation stage. These decreases in mRNA levels in bovine mammary tissue have been shown to be species specific (Plath-Gabler et al., 2001).

\section{IGFBPs}

Different types of IGF-1R transcripts have been discovered in bovine mammary glands (Glimm et al., 1992). IGFBPs, which are encoded by six similar transcripts, are regulated based on their interactions with IGFs and their specific binding proteins (Ballard et al., 1989). The interactions of IGFBPs with IGF have been characterized in several studies. IGFBP bioactivity inhibits the functions of IGF-I and IGF-II by competition with IGF-IR and IGF-IIR through IGF-I and IGF-II near the cell surface. Furthermore, IGFs and IGFBPs can influence interactions with other growth pathways or IGF-independent functions (Kelley et al., 1996; Werner \& LeRoith, 1996). The interactions between IGFBPs and IGFs are regulated by proteases by affecting the binding affinity of IGFBP for IGFs.

Modifications of IGFBPs, such as protein phosphorylation and binding with other factors, may affect their interactions with other proteins (McCusker et al., 1990; Oh, 1998). For example, when IGFBP-1 binds to integrin, IGFBP-3 binding at the cell surface is decreased because the specific affinity of IGFBP-3 for IGF-1 is reduced when IGFBP-3 interacts with cell surface molecules (Conover \& Powell, 1991). Moreover, suppression of IGF-I release from IGFBP-3 may occur through the interaction between IGFs and IGFIR, thus reducing the activity of IGFs. IGFBP expression 


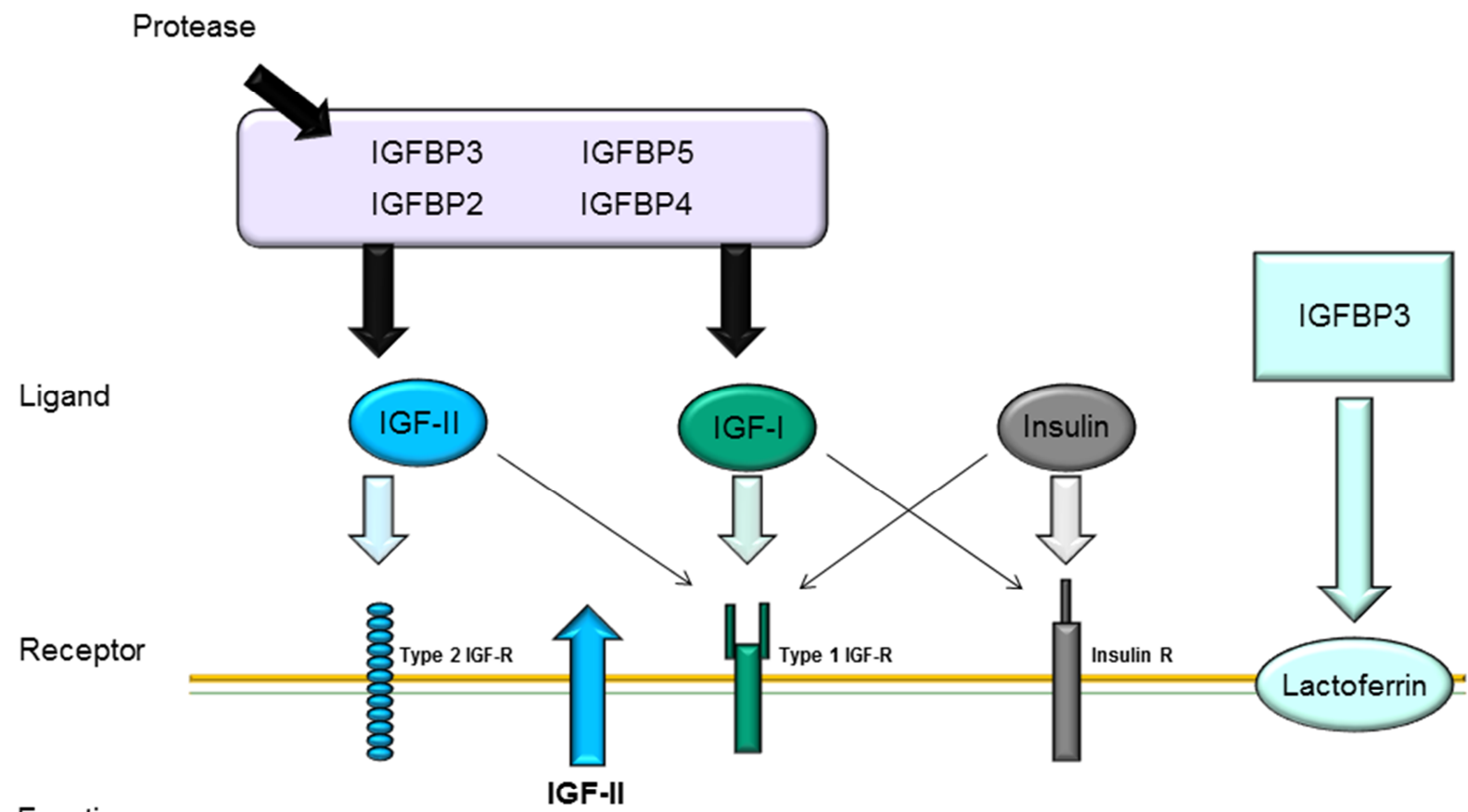

Function

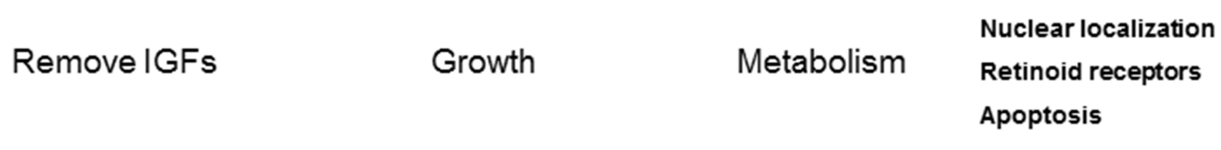

Fig. 2. Description of IGF system components in mammary gland epithelial cells.

during mammary gland development has also been studied by analysis of the contributions of IGFBP-2 and -5 to branching mammogenesis during pregnancy (Wood \& Yee, 2000).

All IGFBPs exhibit high-affinity binding with IGFs; however, IGFBPs also have other functions independent of IGFs. IGFBP-1 and -2 include the tripeptide Arg-Gly-Asp (RGD) sequence, which is recognized by cell surface integrins and cell adhesion molecules. IGFBP-1 overexpression in Chinese hamster cells increases cell migration (Jones et al., 1993). Additionally, IGFBP-3 has independent effects on the modulation of $\mathrm{Bax}$ and $\mathrm{Bcl}-2$, inducing apoptosis in human breast cancer cells through IGF-I (Butt et al., 2000) and inhibiting proliferation in type I IGF receptor-knockout mice (Valentinis et al., 1995). Recent studies have demonstrated that IGFBP-3 regulates transforming growth factor (TGF)- $\beta$ during programmed cell death through interactions between p53 and IGF-independent signaling (Rajah et al., 1997). Additionally, the TGF- $\beta$ receptor can interact with IGFBP-3 (Leal et al., 1997). Moreover, IGFBP-5 has been shown to activate DNA synthesis in osteoblasts through a pathway independent of IGF-I (Andress, 1995). Both IGFBP-3 and -5 contain a putative nuclearlocalization sequence (NLS) (Radulescu, 1994) and have been shown to be expressed in the nuclei using immunelogical localization methods (Jaques et al., 1997; Schedlich et al., 2000). These results suggest that IGFBPs can also contribute to intracellular functions, such as proliferation, apoptosis, and cell migration. Thus, these observations also provide insights into whether the high concentrations of IGFBP-5 in bovine milk interact with IGF-dependent or -independent pathways. In human milk production, IGFBP2 is more highly expressed than IGFBP-1 and IGFBP-3 (Erickson et al., 1993; Donovan \& Odle, 1994), and IGFBP-1 and IGFBP-3 are present at lower concentrations than IGFBP-2 in human milk. Porcine milk contains IGFBP-14. mRNAs encoding IGFBP-2 and -3 are expressed in porcine 
mammary glands (Simmen et al., 1988). Thus, IGFBP-2 and 3 in milk is derived from the mammary glands. In bovine serum, IGFBP-2 is highly expressed during the early lactation stage and decreased during the dry period (Vicini et al., 1991). Rat milk contains IGFBP-2-4, as detected by western blotting. IGFBP-2 is not expressed in maternal serum, but is expressed in lactating mammary glands, suggesting that IGFBP-2 is synthesized in mammary glands. IGFBP-4 expression has been identified in rat mammary glands, although the concentration is lower than that in serum (Donovan et al., 1995). IGFBP-5 and -6 are not present in milk during the lactation stage. IGFs and IGFBPs may enter milk from the serum by paracellular interactions and secretion by epithelial cells. However, involuting mammary glands exhibit increased levels of IGFBP-2,IGFBP-4, and IGFBP-5 mRNAs. IGF-1 is a survival factor for several different types of cells and is regulated by GH (Travers et al., 1996). Of all the hormonal changes that occur during the involution stage, PRL is able to influence only IGFBP-5 synthesis, suggesting that the prolactin is a potential inhibitor of IGFBP-5.

\section{CONCLUSION}

In bovine mammary glands, mammary gland development occurs through complex regulation of the IGF pathway. Although IGF pathway ligands (IGF-I, IGF-II, and insulin) affect various cellular mechanisms, including proliferation, migration, and apoptosis, the roles of these ligands in mammary gland development depend on associations with their specific receptors, e.g., IGFBPs and IGF-R. Fig. 2 describes the general interactions among IGFBPs, ligands, and their specific receptors in mammary epithelial cells. IGFs cannot interact with their receptors when IGF-I and IGF-II bind to IGFBPs owing to competitive interactions between IGF and IGFBPs. IGFBPs are degraded by proteases, whereas IGFs are free to bind with IGF receptors. IGFBPs are present in bovine serum, whereas IGFBPs are expressed in mammary epithelial cells. In addition, IGFBPs are secreted in bovine milk derived from mammary gland epithelial cells. Furthermore, at the involution stage, IGFBPs are decreased in milk and epithelial cells, along with PRL and $\mathrm{GH}$, resulting in degradation of mammary glands. Mammary glands are considered highly sensitive to hormones and IGF signal transduction during the developmental stage. Therefore, improving our understanding of and IGFBP interactions and secretion during mammary gland development may facilitate increased milk productivity through induction of mammogenesis.

\section{ACKNOWLEDGEMENTS}

This work was supported by dairy cow project (grant no. PJ010924) funded by the Rural Development Administration of Korea.

\section{REFERENCES}

Andress DL (1995) Heparin modulates the binding of insulin-like growth factor (IGF) binding protein-5 to a membrane protein in osteoblastic cells. J Biol Chem 270:28289-28296.

Ballard FJ, Francis GL, Bagley CJ, Szabo L, Wallace JC (1989) Effects of insulin-like growth factors on protein metabolism: Why are some molecular variants more potent? Biochem Soc Symp 55:91-104.

Baumrucker CR, Campana WM, Gibson CA, Kerr DE (1993) Insulin-like growth factors (IGF) and IGF binding proteins in milk; sources and functions. Endocr Regul 27:157-172.

Butt AJ, Firth SM, King MA, Baxter RC (2000) Insulinlike growth factor-binding protein-3 modulates expression of Bax and Bcl-2 and potentiates p53-independent radiation-induced apoptosis in human breast cancer cells. J Biol Chem 275:39174-39181.

Conover CA, Powell DR (1991) Insulin-like growth factor 
(IGF)-binding protein-3 blocks IGF-I-induced receptor down-regulation and cell desensitization in cultured bovine fibroblasts. Endocrinology 129:710-716.

Donovan SM, Hintz RL, Rosenfeld RG (1995) Investigation into the potential physiological sources of rat milk IGF-I and IGF-binding proteins. J Endocrinol 145:569-578.

Donovan SM, Odle J (1994) Growth factors in milk as mediators of infant development. Annu Rev Nutr 14: 147-167.

Erickson GF, Nakatani A, Ling N, Shimasaki S (1993) Insulin-like growth factor binding protein-3 gene expression is restricted to involuting corpora lutea in rat ovaries. Endocrinology 133:1147-1157.

Gibson CA, Staley MD, Baumrucker CR (1999) Identification of IGF binding proteins in bovine milk and the demonstration of IGFBP-3 synthesis and release by bovine mammary epithelial cells. J Anim Sci 77:15471557.

Glimm DR, Baracos VE, Kennelly JJ (1992) Northern and in situ hybridization analyses of the effects of somatotropin on bovine mammary gene expression. J Dairy Sci 75:2687-2705.

Hadsell DL, Campbell PG, Baumrucker CR (1990) Characterization of the change in type I and II insulin-like growth factor receptors of bovine mammary tissue during the pre- and postpartum periods. Endocrinology 126:637-643.

Howlin J, McBryan J, Martin F (2006) Pubertal mammary gland development: Insights from mouse models. J Mammary Gland Biol Neoplasia 11:283-297.

Jaques G, Noll K, Wegmann B, Witten S, Kogan E, Radulescu RT, Havemann K (1997) Nuclear localization of insulinlike growth factor binding protein 3 in a lung cancer cell line. Endocrinology 138:1767-1770.

Jones JI, Clemmons DR (1995) Insulin-like growth factors and their binding proteins: biological actions. Endocr Rev 16:3-34.
Jones JI, Gockerman A, Busby WH, Wright G, Clemmons DR (1993) Insulin-like growth factor binding protein 1 stimulates cell migration and binds to the alpha 5 beta 1 integrin by means of its Arg-Gly-Asp sequence. Proc Natl Acad Sci U S A 90:10553-10557.

Kelley KM, Oh Y, Gargosky SE, Gucev Z, Matsumoto T, Hwa V, Ng L, Simpson DM, Rosenfeld RG (1996) Insulin-like growth factor-binding proteins (IGFBPs) and their regulatory dynamics. Int J Biochem Cell Biol 28:619-637.

Kleinberg DL (1997) Early mammary development: Growth hormone and IGF-1. J Mammary Gland Biol Neoplasia 2:49-57.

Le Roith D (2003) The insulin-like growth factor system. Exp Diabesity Res 4:205-212.

Leal SM, Liu Q, Huang SS, Huang JS (1997) The type V transforming growth factor beta receptor is the putative insulin-like growth factor-binding protein 3 receptor. J Biol Chem 272:20572-20576.

Macias H, Hinck L (2012) Mammary gland development. Wiley Interdiscip Rev Dev Biol 1: 533-557.

Massague J, Blinderman LA, Czech MP (1982) The high affinity insulin receptor mediates growth stimulation in rat hepatoma cells. J Biol Chem 257:13958-13963.

McCusker RH, Camacho-Hubner C, Bayne ML, Cascieri MA, Clemmons DR (1990) Insulin-like growth factor (IGF) binding to human fibroblast and glioblastoma cells: The modulating effect of cell released IGF binding proteins (IGFBPs). J Cell Physiol 144:244-253.

Oh Y (1998) IGF-independent regulation of breast cancer growth by IGF binding proteins. Breast Cancer Res Treat 47:283-293.

Pispa J, Thesleff I (2003) Mechanisms of ectodermal organogenesis. Dev Biol 262:195-205.

Plath-Gabler A, Gabler C, Sinowatz F, Berisha B, Schams D (2001) The expression of the IGF family and GH receptor in the bovine mammary gland. J Endocrinol 
$168: 39-48$.

Radulescu RT (1994) Nuclear localization signal in insulinlike growth factor-binding protein type 3. Trends Biochem Sci 19:278.

Rajah R, Valentinis B, Cohen P (1997) Insulin-like growth factor (IGF)-binding protein-3 induces apoptosis and mediates the effects of transforming growth factorbeta1 on programmed cell death through a p53- and IGF-independent mechanism. J Biol Chem 272:1218112188.

Rechler MM, and Nissley SP (1985) The nature and regulation of the receptors for insulin-like growth factors. Annu Rev Physiol 47:425-442.

Richard-Parpaillon L, Heligon C, Chesnel F, Boujard D, Philpott A (2002) The IGF pathway regulates head formation by inhibiting Wnt signaling in Xenopus. Dev Biol 244:407-417.

Rota LM, Wood TL (2015) Crosstalk of the insulin-like growth factor receptor with the Wnt signaling pathway in breast cancer. Front Endocrinol (Lausanne) 6:92.

Ruan W, Catanese V, Wieczorek R, Feldman M, Kleinberg DL (1995) Estradiol enhances the stimulatory effect of insulin-like growth factor-I (IGF-I) on mammary development and growth hormone-induced IGF-I messenger ribonucleic acid. Endocrinology 136:1296-1302.

Ruan W, Newman CB, Kleinberg DL (1992) Intact and amino-terminally shortened forms of insulin-like growth factor I induce mammary gland differentiation and development. Proc Natl Acad Sci U S A 89:1087210876.

Schedlich LJ, Le Page SL, Firth SM, Briggs LJ, Jans DA, Baxter RC (2000) Nuclear import of insulin-like growth factor-binding protein- 3 and -5 is mediated by the importin beta subunit. J Biol Chem 275:23462-23470.

Sharma BK, Vandehaar MJ, Ames NK (1994) Expression of insulin-like growth factor-I in cows at different stages of lactation and in late lactation cows treated with somatotropin. J Dairy Sci 77:2232-2241.

Simmen FA, Simmen RC, Reinhart G (1988) Maternal and neonatal somatomedin C/insulin-like growth factor-I (IGF-I) and IGF binding proteins during early lactation in the pig. Dev Biol 130:16-27.

Travers MT, Barber MC, Tonner E, Quarrie L, Wilde CJ, Flint DJ (1996) The role of prolactin and growth hormone in the regulation of casein gene expression and mammary cell survival: Relationships to milk synthesis and secretion. Endocrinology 137:1530-1539.

Valentinis B, Bhala A, DeAngelis T, Baserga R, Cohen P (1995) The human insulin-like growth factor (IGF) binding protein-3 inhibits the growth of fibroblasts with a targeted disruption of the IGF-I receptor gene. Mol Endocrinol 9:361-367.

Vicini JL, Buonomo FC, Veenhuizen JJ, Miller MA, Clemmons DR, Collier RJ (1991) Nutrient balance and stage of lactation affect responses of insulin, insulin-like growth factors I and II, and insulin-like growth factor-binding protein 2 to somatotropin administration in dairy cows. J Nutr 121:1656-1664.

Werner H, LeRoith D (1996) The role of the insulin-like growth factor system in human cancer. Adv Cancer Res 68:183-223.

Wood TL, Yee D (2000) Introduction: IGFs and IGFBPs in the normal mammary gland and in breast cancer. $\mathrm{J}$ Mammary Gland Biol Neoplasia 5:1-5. 